\title{
Unprecedented in Vitro
}

Antitubercular Activitiy of Manganese(II) Complexes Containing 1,10-Phenanthroline and Dicarboxylate Ligands: Increased Activity, Superior Selectivity, and Lower Toxicity in Comparison to Their Copper(II) Analogs

\section{OPEN ACCESS}

Edited by:

Rustam Aminov,

University of Aberdeen,

United Kingdom

Reviewed by:

Thomas Dick,

Rutgers, The State University of New Jersey, United States Naresh Singhal,

University of Auckland, New Zealand

*Correspondence:

Malachy McCann

malachy.mccann@mu.ie

Fernando R. Pavan

fernandopavan@fcfar.unesp.br

Specialty section:

This article was submitted to Antimicrobials, Resistance and

Chemotherapy,

a section of the journal

Frontiers in Microbiology

Received: 05 April 2018 Accepted: 11 June 2018

Published: 02 July 2018

Citation:

McCarron P, McCann M, Devereux M, Kavanagh K, Skerry C, Karakousis PC,

Aor AC, Mello TP, Santos ALS,

Campos DL and Pavan FR (2018) Unprecedented in Vitro Antitubercular Activitiy of Manganese(II) Complexes

Containing 1,10-Phenanthroline and

Dicarboxylate Ligands: Increased

Activity, Superior Selectivity, and Lower Toxicity in Comparison to Their

Copper(II) Analogs.

Front. Microbiol. 9:1432.

doi: 10.3389/fmicb.2018.01432
Pauraic McCarron ${ }^{1,2}$, Malachy McCann ${ }^{1 *}$, Michael Devereux ${ }^{2}$, Kevin Kavanagh $^{3}$, Ciaran Skerry ${ }^{4}$, Petros C. Karakousis ${ }^{4}$, Ana C. Aor ${ }^{5}$, Thaís P. Mello ${ }^{5}$, André L. S. Santos ${ }^{5}$, Débora L. Campos ${ }^{6}$ and Fernando R. Pavan ${ }^{6 *}$

${ }^{1}$ Chemistry Department, Maynooth University, National University of Ireland, Maynooth, Ireland, ${ }^{2}$ The Center for Biomimetic and Therapeutic Research, Focas Research Institute, Dublin Institute of Technology, Dublin, Ireland, ${ }^{3}$ Biology Department, Maynooth University, National University of Ireland, Maynooth, Ireland, ${ }^{4}$ Division of Infectious Diseases, Center for Tuberculosis Research, Department of Medicine, Johns Hopkins School of Medicine, Baltimore, MD, United States, ${ }^{5}$ Departamento de Microbiologia Geral, Instituto de Microbiologia Paulo de Góes, Universidade Federal do Rio de Janeiro, Rio de Janeiro, Brazil, ${ }^{6}$ Faculdade de Ciências Farmacêuticas, Universidade Estadual Paulista, Araraquara, São Paulo, Brazil

Mycobacterium tuberculosis is the etiologic agent of tuberculosis. The demand for new chemotherapeutics with unique mechanisms of action to treat (multi)resistant strains is an urgent need. The objective of this work was to test the effect of manganese(II) and copper(II) phenanthroline/dicarboxylate complexes against $M$. tuberculosis. The water-soluble $\mathrm{Mn}(\mathrm{II})$ complexes, $\left.\left[\mathrm{Mn}_{2} \text { (oda)(phen }\right)_{4}\left(\mathrm{H}_{2} \mathrm{O}\right)_{2}\right]\left[\mathrm{Mn}_{2}\right.$ (oda)(phen) $\left.{ }_{4}(\text { oda })_{2}\right] \cdot 4 \mathrm{H}_{2} \mathrm{O}$ (1) and $\left\{\left[\mathrm{Mn}(3,6,9 \text {-tdda)(phen) })_{2}\right] \cdot 3 \mathrm{H}_{2} \mathrm{O} \cdot \mathrm{EtOH}\right\} \mathrm{n}$ (3) $\left(\mathrm{odaH}_{2}=\right.$ octanedioic acid, phen $=$ 1,10-phenanthroline, tddaH $_{2}=3,6,9$-trioxaundecanedioic acid), and water-insoluble complexes, [Mn(ph)(phen) $\left.\left(\mathrm{H}_{2} \mathrm{O}\right)_{2}\right] \quad(\mathbf{5}), \quad\left[\mathrm{Mn}(\mathrm{ph})(\text { phen })_{2}\left(\mathrm{H}_{2} \mathrm{O}\right)\right] \cdot 4 \mathrm{H}_{2} \mathrm{O}$ (6), $\left.\quad\left[\mathrm{Mn}_{2} \text { (isoph) }\right)_{2}(\text { phen })_{3}\right] \cdot 4 \mathrm{H}_{2} \mathrm{O} \quad(\mathbf{7}), \quad\left\{\left[\mathrm{Mn}(\text { phen })_{2}\left(\mathrm{H}_{2} \mathrm{O}\right)_{2}\right]\right\}_{2}$ (isoph) $)_{2}$ (phen) $\cdot 12 \mathrm{H}_{2} \mathrm{O}$ (8) and $\left.[\mathrm{Mn} \text { (tereph)(phen) })_{2}\right] \cdot 5 \mathrm{H}_{2} \mathrm{O}$ (9) $\left(\mathrm{phH}_{2}=\right.$ phthalic acid, isophH $\mathrm{H}_{2}=$ isophthalic acid, tereph $\mathrm{H}_{2}=$ terephthalic acid), robustly inhibited the viability of M. tuberculosis strains, H37Rv and CDC1551. The water-soluble $\mathrm{Cu}(\mathrm{II})$ analog of (1), $\left.\left[\mathrm{Cu}_{2} \text { (oda)(phen) }\right)_{4}\right]\left(\mathrm{ClO}_{4}\right)_{2} \cdot 2.76 \mathrm{H}_{2} \mathrm{O} \cdot \mathrm{EtOH}(\mathbf{2})$, was significantly less effective against both strains. Whilst (3) retarded H37Rv growth much better than its soluble $\mathrm{Cu}(\mathrm{II})$ equivalent, $\left\{\left[\mathrm{Cu}(3,6,9 \text {-tdda)(phen) })_{2}\right] \cdot 3 \mathrm{H}_{2} \mathrm{O} \cdot \mathrm{EtOH}\right\} \mathrm{n}(\mathbf{4})$, both were equally efficient against CDC1551. VERO and A549 mammalian cells were highly tolerant to the $\mathrm{Mn}(\mathrm{II})$ complexes, culminating in high selectivity index (SI) values. Significantly, in vivo studies using Galleria mellonella larvae indicated that the metal complexes were minimally toxic to the larvae. The Mn(II) complexes presented low MICs and high SI values (up to 1347), indicating their auspicious potential as novel antitubercular lead agents.

Keywords: Mycobacterium tuberculosis, manganese(II), 1, 10-phenanthroline, metal-based complex, antimicrobial agent, Galleria mellonella 


\section{INTRODUCTION}

Mycobacterium tuberculosis is a pathogenic, acid-alcohol resistant bacillus and is responsible for the highly contagious and potentially fatal disease, tuberculosis (TB) (Ryan et al., 2014). The bacterium has an unusual, impermeable, waxy coating composed mainly of mycolic acids, a feature in part responsible for its inherent resistance to numerous drugs. The infected host is thought to contain populations of $M$. tuberculosis in cavitary lesions, closed caseous lesions, and within macrophages (Bennett, 1994). In cavities, the oxygen level is high, the medium is neutral or slightly alkaline and replication is relatively fast. With the other two populations, the oxygen concentration is lower, the medium is neutral or acidic and multiplication is slower. The disease most commonly involves the lungs and is readily spread via aerosol. However, the infection may also spread to distant sites, such as the brain, kidneys, spleen, liver, and bones (Krishnan et al., 2010). In 2016, there were 9.6 million new cases of TB and 1.5 million deaths (Who.int). Furthermore, there has been an alarming rise in the number of patients presenting with multidrug-resistant (MDR) TB, which is defined by resistance to the two front-line drugs, isoniazid (INH), and rifampicin, and extensively drug-resistant (XDR) TB, which additionally exhibits resistance to two of the most important second-line drug classes (fluoroquinolones and injectable agents). The World Health Organization estimated that ca. 4,80,000 people developed MDR-TB in the world in 2014, and that $9.7 \%$ of these cases had XDR-TB (Who.int). The treatment for MDR-TB and XDR-TB is costly, toxic, lengthy and less effective than the standard regime, which contributes to medical non-adherence and the emergence of totally drug-resistant strains (TDR-TB). Clearly, in order to effectively treat these highly resistant strains of $M$. tuberculosis there is an urgent need for new drug classes possessing novel mechanisms of action.

Throughout classical antiquity, empirical formulations comprising metal ions have been used for medicinal purposes. However, following the discovery of penicillin and other drugs of biological and synthetic organic origin the clinical use of metallo compounds declined markedly. But within the past 50 years there has been a renaissance in metal-based pharmaceuticals, driven mainly by problems of efficacy and resistance. Some examples of therapeutically important, metal-containing systemic drugs include platinum and arsenic for cancer treatment, samarium for metastatic tumor pain relief, gold as an anti-arthritic, bismuth as a gastrointestinal antimicrobial, antimony and arsenic as anti-parasitics, iron in cardiovascular disease, lithium for bipolar disorder, barium and gadolinium as diagnostic imaging agents, radioactive isotopes of gallium, indium and technetium in tomography, and radiopharmaceuticals containing strontium, yttrium, samarium, and radium (Gielen and Tiekink, 2005; Dabrowiak, 2009; Mjos and Orvig, 2014). Nanoparticulate silver and silver salts are also being applied topically as antibacterial agents in wound and burn treatments (Stobie et al., 2008; Landsdown, 2010).

There are numerous examples where transition metal complexes have been shown to inhibit the growth of $M$. tuberculosis in vitro. Integration of metal ions into the drug structure offers structural diversity, possible access to numerous oxidation states of the metal and the potential of enhancing the efficacy of an established organic drug through its coordination to the metal (Viganor et al., 2015). Metal complexes containing a variety of ligands, such as thiosemicarbazones, quinolones, amines, imines and phenanthrolines, have shown substantial growth inhibition of $M$. tuberculosis. Mechanistic studies have been conducted on metal ligated by the pro-drug INH and some of its derivatives. In particular, the octahedral Fe(II) complex trianion, $\left[\mathrm{Fe}(\mathrm{CN})_{5}(\mathrm{INH})\right]^{3-}$, which returned a MIC value of $0.43 \mu \mathrm{M}$ (based on $\mathrm{Na}_{3}\left[\mathrm{Fe}(\mathrm{CN})_{5}(\mathrm{INH})\right] \cdot 4 \mathrm{H}_{2} \mathrm{O}$ ), has been scrutinized in detail (Oliveira et al., 2004). Studies have inferred that the mode of action of INH in blocking the synthesis of $M$. tuberculosis cell wall mycolic acids is linked to the in situ formation of coordination complexes with redox-active metal ions like $\mathrm{Cu}(\mathrm{II})$ and $\mathrm{Fe}(\mathrm{II})$ (BernardesGénisson et al., 2013). In the case of $\left[\mathrm{Fe}(\mathrm{CN})_{5}(\mathrm{INH})\right]^{3-}$, it is believed that the $\mathrm{Fe}(\mathrm{II})$ center initiates the oxidation of the coordinated INH to form a bioactive species that confers in vitro and in vivo growth inhibition activity against both INH-sensitive and INH-resistant strains of M. tuberculosis. In addition, cytotoxicity studies with $\left[\mathrm{Fe}(\mathrm{CN})_{5}(\mathrm{INH})\right]^{3-}$ against mammalian cancer cells showed $\mathrm{IC}_{50}$ values $>54 \mu \mathrm{M}$, which translated to a credible selectivity index (SI) of $>125$ (Oliveira et al., 2004). More recently, Poggi et al. (2013) reported MIC values of 2.2 and $0.41 \mu \mathrm{M}$ for the respective $\mathrm{INH}$-containing $\mathrm{Cu}(\mathrm{II})$ and $\mathrm{Co}(\mathrm{II})$ complexes, $\left[\mathrm{Cu}(\mathrm{INH})\left(\mathrm{H}_{2} \mathrm{O}\right)\right] \mathrm{SO}_{4} \cdot 2 \mathrm{H}_{2} \mathrm{O}$ and $\left[\mathrm{CoCl}(\mathrm{INH})_{2}\left(\mathrm{H}_{2} \mathrm{O}\right)\right] \mathrm{Cl} \cdot 2.5 \mathrm{H}_{2} \mathrm{O}$, against $M$. tuberculosis $\mathrm{H} 37 \mathrm{Rv}$. Both complexes were only very sparingly soluble in water and thought to be more lipophilic than uncoordinated INH. Very encouraging SI values, established using VERO epithelial cells (ATCC CCL81) and macrophage J774A.1 cells (ATCC TIB-67) were obtained for the $\mathrm{Cu}(\mathrm{II})$ and $\mathrm{Co}(\mathrm{II})$ complexes.

In 1969, Dwyer et al. (1969) published their comprehensive, landmark treatise on the in vitro and in vivo antibacterial activities of dicationic $\mathrm{Mn}$ (II), $\mathrm{Fe}(\mathrm{II}), \mathrm{Co}(\mathrm{II}), \mathrm{Ni}(\mathrm{II})$, $\mathrm{Cu}(\mathrm{II}), \mathrm{Zn}(\mathrm{II}), \mathrm{Cd}(\mathrm{II})$, and $\mathrm{Ru}(\mathrm{II})$ chelates containing 1,10-phenanthroline (phen), substituted phen (R-phen), 2.2'bipyridine (bipy), and substituted bipy (R-bipy) ligands. Against M. tuberculosis $\mathrm{H} 37 \mathrm{Rv}$ the bipy complexes were considerably less potent than their phen analogs. Metal centers chelated by the $5-\mathrm{NO}_{2}$-phen ligand showed the most potent antitubercular activity, with the substitutionally-inert $\mathrm{Ru}(\mathrm{II})$ tris chelate being 128-fold less active. Importantly, the bacilli did not develop significant resistance to the $5-\mathrm{NO}_{2}$-phen complexes. However, treatment with the phen complexes did not increase the survival of M. tuberculosis-infected mice relative to the untreated rodent (Dwyer et al., 1969). The low in vivo activity was attributed to either poor bioavailability at doses safe for the host and/or a failure to access locations where the organism proliferates. More recently, Hoffman and coworkers (Hoffman et al., 2013) prepared mono- and binuclear $\mathrm{Co}(\mathrm{II})$ and $\mathrm{Cu}(\mathrm{II})$ phen complexes incorporating the water-solubilizing pyrophosphate ligands, formulating as $\left\{\left[\mathrm{Co}(\text { phen })_{2}\right]_{2}\left(\mu-\mathrm{P}_{2} \mathrm{O}_{7}\right)\right\}$, $\left[\mathrm{Co}(\text { phen })_{2}\left(\mathrm{H}_{2} \mathrm{P}_{2} \mathrm{O}_{7}\right)\right]$, $\left\{[\mathrm{Cu}(\text { phen })]_{2}\left(\mu-\mathrm{P}_{2} \mathrm{O}_{7}\right)\right\}$, and $\left[\mathrm{Cu}(\right.$ phen $\left.)\left(\mathrm{H}_{2} \mathrm{O}\right)\left(\mathrm{H}_{2} \mathrm{P}_{2} \mathrm{O}_{7}\right)\right]$. Mononuclear $\left[\mathrm{Cu}(\right.$ phen $\left.)\left(\mathrm{H}_{2} \mathrm{O}\right)\left(\mathrm{H}_{2} \mathrm{P}_{2} \mathrm{O}_{7}\right)\right]$ was the least active against $M$. tuberculosis $\mathrm{H} 37 \mathrm{Rv}(\mathrm{MIC}=71.53 \mu \mathrm{M})$ whilst its 
mono-Co(II) analog was the most potent $(2.05 \mu \mathrm{M})$. In addition, all substances were active against MDR ATCC 49967, with the dinuclear complexes, $\left\{\left[\mathrm{M}(\mathrm{phen})_{2}\right]_{2}\left(\mu-\mathrm{P}_{2} \mathrm{O}_{7}\right)\right\}$, showing the greatest activity (MIC values of 2.41 and $2.80 \mu \mathrm{M}$, respectively, for $\mathrm{Co}(\mathrm{II})$ and $\mathrm{Cu}(\mathrm{II})$ derivatives). Additionally, SI values (based on A549 cells) for the $\mathrm{Co}$ (II) complexes were much larger than those of their respective $\mathrm{Cu}$ (II) counterparts. The complexes resisted efflux mechanisms in mycobacteria and interfered with multiple biochemical pathways. Dholariya et al. (2013) reported the antitubercular activities of $\mathrm{Cu}$ (II) complexes ligated by dicoumarol (dicoum) derivatives and phen, formulated as $\left[\mathrm{Cu}(\right.$ dicoum $)($ phen $\left.)\left(\mathrm{H}_{2} \mathrm{O}\right)(\mathrm{OH})\right] \cdot \mathrm{xH}_{2} \mathrm{O}$ (Devereux et al., 2000). Against M. tuberculosis H37Rv, only complexes incorporating hydroxylated $(-3-\mathrm{OH})$ and chlorinated (-4-Cl) dicoumarols showed appreciable activity $\left(\mathrm{MIC}_{90}=\right.$ 4.05 and $64.8 \mu \mathrm{M}$, respectively). Patel et al. (2012) tested an array of similar $\mathrm{Cu}(\mathrm{II})$ acyl coumarin/phen complexes which displayed only moderate anti-M. tuberculosis activity (MIC range 49.5->243 $\mu \mathrm{M}$ ). Segura et al. (2014) synthesized $\mathrm{Ag}(\mathrm{I})$ thiourea $(\mathrm{tu}) / \mathrm{phen}$ complexes, $\left[\{\mathrm{Ag}(\text { phen })(\mu-\mathrm{tu})\}_{2}\right] \mathrm{X}_{2} \quad(\mathrm{X}=$ $\left.\mathrm{NO}_{3}^{-}, \mathrm{CF}_{3} \mathrm{SO}_{3}^{-}\right)$, having $\mathrm{MIC}$ values of 11.0 and $14.2 \mu \mathrm{M}(\mathrm{X}=$ $\mathrm{NO}_{3}^{-}$and $\mathrm{CF}_{3} \mathrm{SO}_{3}^{-}$, respectively) against $\mathrm{H} 37 \mathrm{Rv}$.

In the present study, we report the in vitro anti- $M$. tuberculosis activity of the water-soluble $\mathrm{Mn}(\mathrm{II})$ and $\mathrm{Cu}(\mathrm{II})$ phen/dicarboxylate complexes (Figures 1,2), $\left[\mathrm{Mn}_{2}\right.$ (oda) (phen $\left.\left.)_{4} \quad\left(\mathrm{H}_{2} \mathrm{O}\right)_{2}\right]\left[\mathrm{Mn}_{2} \text { (oda)(phen }\right)_{4}(\text { oda })_{2}\right] \cdot 4 \mathrm{H}_{2} \mathrm{O}(\mathbf{1})$, $\left.\left[\mathrm{Cu}_{2} \text { (oda)(phen }\right)_{4}\right](\mathrm{ClO} 4)_{2} \cdot 2.76 \mathrm{H}_{2} \mathrm{O} \cdot \mathrm{EtOH} \quad(2), \quad\{[\mathrm{Mn}(3,6,9-$ tdda)(phen $\left.\left.)_{2}\right] \quad \cdot 3 \mathrm{H}_{2} \mathrm{O} \cdot \mathrm{EtOH}\right\} \mathrm{n} \quad(3) \quad$ and $\quad\{[\mathrm{Cu}(3,6,9-$ tdda)(phen $\left.\left.)_{2}\right] \cdot 3 \mathrm{H}_{2} \mathrm{O} \cdot \mathrm{EtOH}\right\} \mathrm{n}$ (4) $\left(\right.$ odaH $_{2}=$ octanedioic acid, $\operatorname{tddaH}_{2}=3,6,9$-trioxaundecanedioic acid) (Figure 2), and the water-insoluble $\mathrm{Mn}(\mathrm{II})$ complexes, $\left[\mathrm{Mn}(\mathrm{ph})(\mathrm{phen})\left(\mathrm{H}_{2} \mathrm{O}\right)_{2}\right]$ (5), $\left[\mathrm{Mn}(\mathrm{ph})(\mathrm{phen})_{2}\left(\mathrm{H}_{2} \mathrm{O}\right)\right] \cdot 4 \mathrm{H}_{2} \mathrm{O}(\mathbf{6}),\left[\mathrm{Mn}_{2}(\text { isoph })_{2}(\mathrm{phen})_{3}\right] \cdot 4 \mathrm{H}_{2} \mathrm{O}$ (7), $\left\{\left[\mathrm{Mn}(\text { phen })_{2}\left(\mathrm{H}_{2} \mathrm{O}\right)_{2}\right]\right\}_{2}(\text { isoph })_{2}($ phen $) \cdot 12 \mathrm{H}_{2} \mathrm{O} \quad(8)$ and $\left[\mathrm{Mn}(\right.$ tereph$\left.)(\mathrm{phen})_{2}\right] \cdot 5 \mathrm{H}_{2} \mathrm{O}(9)\left(\mathrm{phH}_{2}=\right.$ phthalic acid, isophH $\mathrm{H}_{2}$ $=$ isophthalic acid, terephH $\mathrm{H}_{2}=$ terephthalic acid) (Figure 2). In addition, we present toxicity profiling data for the complexes, obtained using mammalian VERO (normal kidney) and A549 (adenocarcinomic alveolar) epithelial cells in vitro and against Galleria mellonella larvae for the in vivo systemic toxicity study.

\section{MATERIALS AND METHODS}

\section{Synthesis of Complexes}

All the chemicals were purchased from commercial sources and used without further purification. Complexes 1-9 (Devereux et al., 2000; Kellett et al., 2011; Gandra et al., 2017) were prepared as previously reported by our group.

\section{Mycobacterial Strains}

The M. tuberculosis strains that were utilized for these studies were the well-characterized laboratory reference strain, H37Rv (ATCC 27294) (Cole et al., 1998) and clinically-derived CDC1551 (Manca et al., 1999).

\section{In Vitro Screening Against M. tuberculosis H37Rv}

The anti-mycobacterial activity of the complexes was determined by the resazurin microtiter assay method (Palomino et al., 2002). Stock solutions of the test complexes were prepared and diluted in Middlebrook 7H9 broth (Difco) supplemented with oleic acid, albumin, dextrose, and catalase (OADC enrichment BBL/Becton-Dickinson), to obtain the final drug concentration range of $0.09-25 \mathrm{mg} / \mathrm{L}$. INH was dissolved in distilled water and was used as control. A suspension of $\mathrm{H} 37 \mathrm{Rv}$ cells was cultured in Middlebrook 7H9 broth supplemented with OADC and 0.05\% Tween-80 until an $\mathrm{OD}_{600}$ of $\approx 1.0$. The culture was diluted to $5 \times$ $10^{5}$ bacilli per $\mathrm{mL}$ and of $100 \mu \mathrm{L}$ were added to each well of a 96well microplate together with equal volumes of the complexes. Samples were set up in triplicate. The plates were incubated for 7 days at $37^{\circ} \mathrm{C}$. Resazurin (solubilized in water) was added $(30 \mu \mathrm{L}$ of $0.01 \%$ ). The fluorescence of the wells was read after $24 \mathrm{~h}$ with a Cytation $3{ }^{\circledR}$. The MIC was defined as the lowest concentration resulting in $90 \%$ inhibition of growth of the bacterium.

\section{In Vitro Screening Against M. tuberculosis CDC1551}

A total of $10^{5}$ bacilli $\left(\mathrm{OD}_{600}=0.5\right)$ were inoculated into separate tubes containing $1 \mathrm{~mL}$ of supplemented Middlebrook 7H9 broth lacking Tween. To these cultures increasing (2-fold) concentrations of test compounds were added and the tubes were left standing at $37^{\circ} \mathrm{C}$ for 14 days. The MIC was defined as the lowest concentration failing to produce a visible pellet.

\section{Mammalian Cell Cytotoxicity}

A549 cytotoxicity was evaluated using the 3-(4,5dimethylthiazol-2-yl)-2,5-diphenyl tetrazolium bromide (MTT; Sigma-Aldrich, USA) assay. A549 lung epithelial cells $\left(10^{4}\right)$ were seeded into tissue culture plates (TPP, Switzerland) and cultured during $24 \mathrm{~h}$ in confluence at $37^{\circ} \mathrm{C}$ in a $5 \% \mathrm{CO}_{2}$ atmosphere. The wells were then washed twice with DMEM to remove non-adherent cells and the test compounds were added in different concentrations (ranging from 0.0313 to 512 $\mathrm{mg} / \mathrm{L}$ ), followed by incubation the plates for $48 \mathrm{~h}$ under the same conditions mentioned above. Subsequently, the cellular viability was evaluated by adding the MTT reagent to each well and by incubating the plates for $3 \mathrm{~h}$, allowing the viable cells containing active mitochondrial dehydrogenases to metabolize the tetrazolium salt into formazan. The formazan crystals were dissolved with DMSO $(100 \mu \mathrm{L})$ and the absorbance was measured using a Thermomax Molecular Device microplate reader at $450 \mathrm{~nm}$. In parallel, cytotoxicity was also performed on normal epithelial cells VERO (ATCC CCL-81) as previously described by Pavan et al. (2010). The cells were incubated at $37^{\circ} \mathrm{C}$ in a humidified $5 \% \mathrm{CO}_{2}$ atmosphere in flasks with a surface area of $12.50 \mathrm{~cm}^{2}$ in DMEM medium $(10 \mathrm{~mL})$ supplemented with $10 \%$ fetal bovine serum, gentamicin sulfate $(50 \mathrm{mg} / \mathrm{L})$ and amphotericin B (2 mg/L). The technique consists of collecting the cells using a solution of trypsin/EDTA, centrifugation $(2,000 \mathrm{rpm}$ for $5 \mathrm{~min}$ ), counting the number of cells in a Neubauer chamber and then adjusting the concentration to $3.4 \times 10^{5}$ cells $/ \mathrm{mL}$ in 


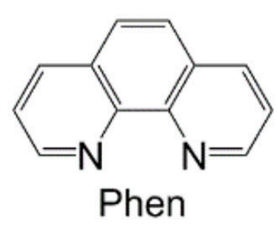<smiles>O=C(O)CCCCCCC(=O)O</smiles><smiles>O=C(O)COCCOCCOCC(=O)O</smiles><smiles>O=C(O)c1ccccc1C(=O)O</smiles><smiles>O=C(O)c1cccc(C(=O)O)c1</smiles>

isophH $\mathrm{H}_{2}$<smiles>O=C(O)c1ccc(C(=O)O)cc1</smiles>

tereph $\mathrm{H}_{2}$

FIGURE 1 | Ligand structures: 1,10-phenanthroline (phen), octanedioic acid $\left(\mathrm{odaH}_{2}\right), 3,6,9$-trioxaundecanedioic acid (tddaH $\left.{ }_{2}\right)$, phthalic acid $\left(\mathrm{phH} \mathrm{H}_{2}\right)$, isophthalic acid (isoph $\mathrm{H}_{2}$ ), terephthalic acid (terephH $\mathrm{H}_{2}$.

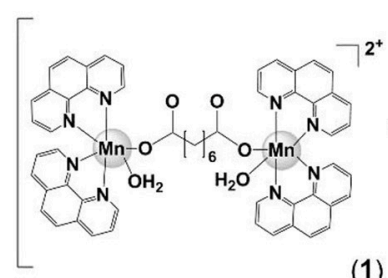

(1)
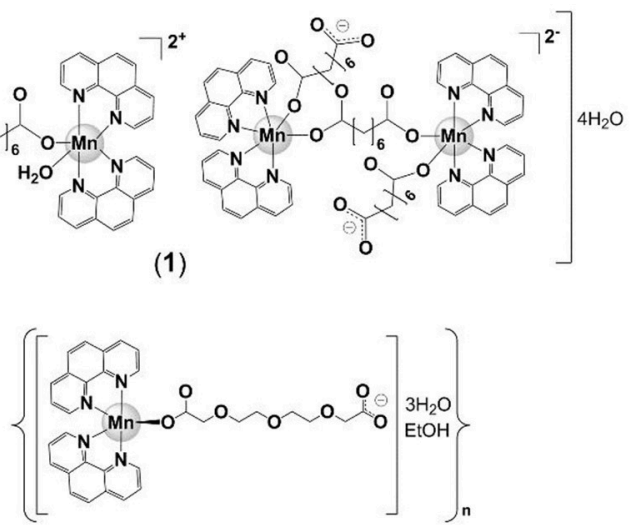

(3)

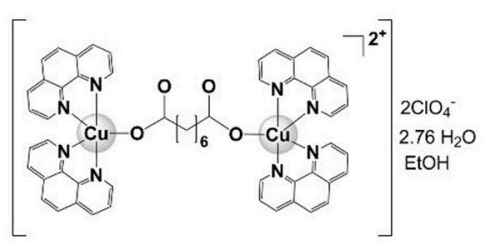

(2)

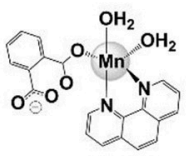

(5)

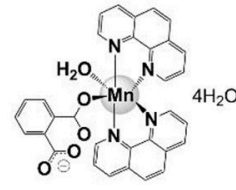

(6)

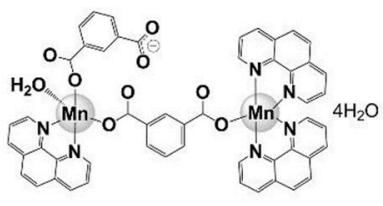

(7)

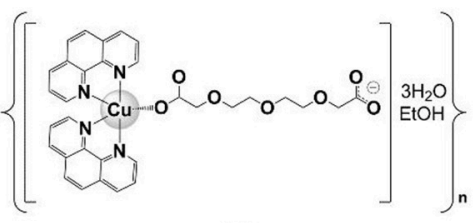

(4)

FIGURE 2 | Proposed structures of complexes utilized for anti-tubercular testing: $\left.\left[\mathrm{Mn}_{2} \text { (oda)(phen }\right)_{4}\left(\mathrm{H}_{2} \mathrm{O}\right)_{2}\right]\left[\mathrm{Mn}_{2}\left(\right.\right.$ oda) $\left.(\text { phen })_{4}(\mathrm{oda})_{2}\right] \cdot 4 \mathrm{H}_{2} \mathrm{O}(\mathbf{1})$, $\left.\left[\mathrm{Cu}_{2} \text { (oda) (phen) }\right)_{4}\right]\left(\mathrm{ClO}_{4}\right)_{2} \cdot 2 \cdot 76 \mathrm{H}_{2} \mathrm{O} \cdot \mathrm{EtOH}(\mathbf{2}),\left\{\left[\mathrm{Mn}(3,6,9-\mathrm{tdda})(\mathrm{phen})_{2}\right] \cdot 3 \mathrm{H}_{2} \mathrm{O} \cdot \mathrm{EtOH}\right\}_{n}(\mathbf{3}),\left\{\left[\mathrm{Cu}(3,6,9-\mathrm{tdda})(\text { phen })_{2}\right] \cdot 3 \mathrm{H}_{2} \mathrm{O} \cdot \mathrm{EtOH}\right\}_{\mathrm{n}}(\mathbf{4}),\left[\mathrm{Mn}(\mathrm{ph})(\mathrm{phen})\left(\mathrm{H}_{2} \mathrm{O}\right)_{2}\right](\mathbf{5})$, $\left[\mathrm{Mn}\left(\right.\right.$ ph) $\left.(\text { phen })_{2}\left(\mathrm{H}_{2} \mathrm{O}\right)\right] \cdot 4 \mathrm{H}_{2} \mathrm{O}(\mathbf{6}),\left[\mathrm{Mn}_{2}(\text { isoph })_{2}(\text { phen })_{3}\right] \cdot 4 \mathrm{H}_{2} \mathrm{O}(\mathbf{7}),\left\{\left[\mathrm{Mn}(\text { phen })_{2}\left(\mathrm{H}_{2} \mathrm{O}\right)_{2}\right]\right\}_{2}(\text { isoph })_{2}($ phen $) \cdot 12 \mathrm{H}_{2} \mathrm{O}(\mathbf{8}),\left[\mathrm{Mn}(\right.$ tereph $\left.)(\text { phen })_{2}\right] \cdot 5 \mathrm{H}_{2} \mathrm{O}(\mathbf{9})$.

DMEM. Then, $200 \mu \mathrm{L}$ of this suspension was deposited in each well of a 96-well microplate to obtain a concentration of $6.8 \times 10^{4}$ cells per well and incubated at $37^{\circ} \mathrm{C}$ in an atmosphere of $5 \% \mathrm{CO}_{2}$ for $24 \mathrm{~h}$ to allow the cells to attach to the microplate. Dilutions on the test compounds were prepared to obtain concentrations from 500 to $1.95 \mathrm{mg} / \mathrm{L}$. The dilutions were added to the cells 
after the medium and the non-adherent cells were removed. The cells were then incubated for an additional $24 \mathrm{~h}$. The cytotoxicity of the compounds was determined by adding $30 \mu \mathrm{L}$ of resazurin and reading on a Synergy $\mathrm{H} 1$ (BioTek ${ }^{\circledR}$ ) reader after $6 \mathrm{~h}$ of incubation using a microplate and excitation and emission filters at wavelengths of $530 \mathrm{~nm}$ and $590 \mathrm{~nm}$, respectively. For both cellular systems, the $50 \%$ cytotoxic concentration $\left(\mathrm{CC}_{50}\right)$ was defined as the compound concentration which caused a $50 \%$ reduction in the number of viable cells. In addition, selectivity index (SI) is calculated as follows: $\mathrm{CC}_{50}$ (mammalian cells)/MIC (M. tuberculosis cells).

\section{In Vivo Cytotoxicity}

G. mellonella larvae in the 6th developmental stage were used to determine the in vivo cytotoxicity of the test complexes (Kellett et al., 2011; Desbois and Coote, 2012; McCann et al., 2012). Thirty healthy larvae, each weighing between 0.2 and $0.4 \mathrm{~g}$ and with no cuticle discolouration, were used for each experiment. Fresh solutions of the test complexes were prepared immediately prior to testing under sterile conditions. Test compounds $(0.05 \mathrm{~g})$ were dissolved in DMSO $(1 \mathrm{~mL})$ and added to sterile water $(9 \mathrm{~mL})$ to give a stock solution/suspension $(5,000 \mu \mathrm{g} / \mathrm{mL})$. Test solutions/suspensions were prepared from the corresponding stock solution using Millipore water only to dilute to the desired concentration and each compound was screened across the concentration range of 5,000-100 mg/L. Test solutions/suspensions $(20 \mu \mathrm{L})$ were administered to the larvae by injection directly into the haemocoel through the last proleg. The base of the pro-leg can be opened by applying gentle pressure to the sides of the larvae and this aperture will reseal after removal of the syringe without leaving a scar. Larvae were placed in sterile Petri dishes and incubated at $30^{\circ} \mathrm{C}$ for $72 \mathrm{~h}$. The survival of the larvae was monitored every $24 \mathrm{~h}$. Death was assessed by the lack of movement in response to stimulus together with discolouration of the cuticle. Three controls were employed in all assays. The first consisted of untouched larvae maintained at the same temperature as the test larvae. The second was larvae with the pro-leg pierced with an inoculation needle but no solution injected. The third control was larvae that were inoculated with $20 \mu \mathrm{L}$ of sterile water.

\section{RESULTS}

\section{Anti-mycobacterial Activity of Metal Complexes}

In vitro growth inhibitory data (MIC values) for the complexes, $\mathrm{MnCl}_{2} \cdot 2 \mathrm{H}_{2} \mathrm{O}$, phen and the first-line anti-mycobacterial agent, $\mathrm{INH}$, against $\mathrm{H} 37 \mathrm{Rv}$ and $\mathrm{CDC} 1551$ strains of $M$. tuberculosis are displayed in Table 1. Based on $\mu \mathrm{M}$ concentrations, the most active of the $\mathrm{Mn}(\mathrm{II})$ complexes against $\mathrm{H} 37 \mathrm{Rv}$ were $\left.\left[\mathrm{Mn}_{2} \text { (oda) (phen }\right)_{4}\left(\mathrm{H}_{2} \mathrm{O}\right)_{2}\right]\left[\mathrm{Mn}_{2}\right.$ (oda) $\left.(\text { phen })_{4}(\text { oda })_{2}\right] \cdot 4 \mathrm{H}_{2} \mathrm{O}$ (1) and $\left\{\left[\mathrm{Mn}(3,6,9-\mathrm{tdda})(\text { phen })_{2}\right] \cdot 3 \mathrm{H}_{2} \mathrm{O} \cdot \mathrm{EtOH}\right\} \mathrm{n}$ (3), which had MIC values comparable to INH $(0.44 \mu \mathrm{M})$. With the exception of the Mn(II) complex (3), all of the metal complexes showed markedly increased inhibitory activity (up to 10-fold in some instances) against strain CDC1551 relative to $\mathrm{H} 37 \mathrm{Rv}$, and many had an MIC value less than that of INH $(0.44 \mu \mathrm{M})$. Against
CDC1551, $\left\{\left[\mathrm{Mn}(\text { phen })_{2}\left(\mathrm{H}_{2} \mathrm{O}\right)_{2}\right]\right\}_{2}(\text { isoph })_{2}$ (phen) $\cdot 12 \mathrm{H}_{2} \mathrm{O}(\mathbf{8}), \mathbf{1}$ and $\left[\mathrm{Mn}_{2} \text { (isoph) }\right)_{2}$ (phen) $\left.)_{3}\right] \cdot 4 \mathrm{H}_{2} \mathrm{O}(7)$ were the most active (MIC range $0.12-0.18 \mu \mathrm{M}$ ), with an almost 3-fold increase in potency compared to INH. The $\mathrm{Cu}(\mathrm{II})$ counterparts of $\mathbf{1}$ and 3, i.e., $\left.\left[\mathrm{Cu}_{2} \text { (oda) (phen }\right)_{4}\right]\left(\mathrm{ClO}_{4}\right)_{2} \cdot 2.76 \mathrm{H}_{2} \mathrm{O} \cdot \mathrm{EtOH}(2)$ and $\{[\mathrm{Cu}(3,6,9-$ tdda)(phen $\left.\left.)_{2}\right] \cdot 3 \mathrm{H}_{2} \mathrm{O} \cdot \mathrm{EtOH}\right\} \mathrm{n}(4)$, were considerably less active against $\mathrm{H} 37 \mathrm{Rv}$, but this disparity was noticeably smaller for the CDC1551 strain, possibly reflecting a degree of specificity by these $\mathrm{d}^{9}$ metal complexes.

\section{Activity Against Mammalian Vero and A549 Epithelial Cells}

In vitro growth inhibitory data ( $\mathrm{IC}_{50}$ values) for the compounds against mammalian VERO and A549 epithelial cells are listed in Table 1. Both cell lines were more tolerant of INH and $\mathrm{MnCl}_{2} \cdot 2 \mathrm{H}_{2} \mathrm{O}$ than phen and the metal-phen complexes. With the exceptions of phen and $\left\{\left[\mathrm{Cu}(3,6,9-\mathrm{tdda})(\text { phen })_{2}\right] \cdot 3 \mathrm{H}_{2} \mathrm{O} \cdot \mathrm{EtOH}\right\} \mathrm{n}$ (4), A549 cells were substantially more passive toward the metal complexes than VERO cells. The two $\mathrm{Cu}$ (II) complexes, $\quad\left[\mathrm{Cu}_{2}(\right.$ oda $\left.)(\text { phen })_{4}\right]\left(\mathrm{ClO}_{4}\right)_{2} \cdot 2.76 \mathrm{H}_{2} \mathrm{O} \cdot \mathrm{EtOH} \quad$ (2) and 4, were more toxic toward these mammalian cell lines than the seven $\mathrm{Mn}$ (II) complexes. Of the $\mathrm{Mn}$ (II) test samples, the water-soluble complex double salt, $\left.\left[\mathrm{Mn}_{2} \text { (oda)(phen }\right)_{4}\left(\mathrm{H}_{2} \mathrm{O}\right)_{2}\right]\left[\mathrm{Mn}_{2}\right.$ (oda) $\left.(\text { phen })_{4}(\text { oda })_{2}\right] \cdot 4 \mathrm{H}_{2} \mathrm{O}(\mathbf{1})$, had the smallest impact on the VERO cells, whilst waterinsoluble $\left[\mathrm{Mn}(\mathrm{ph})(\mathrm{phen})\left(\mathrm{H}_{2} \mathrm{O}\right)_{2}\right]$ (5) was the least cytotoxic against A549 cells.

\section{Activity Against G. mellonella Larvae}

G. mellonella larvae possess an immune system which is analogous to the human innate immune system and are now commonly employed as a convenient, inexpensive, and less ethically sensitive screening model to ascertain the in vivo systemic toxicity of potential drugs, the results of which are comparable to those derived from murine studies (Krishnan et al., 2010; Gandra et al., 2017). Larvae were dosed with varying concentrations of phen and the metal complexes and the percentage of dead larvae was recorded (Table 2). At the highest administered concentration of $0.1 \mathrm{mg}(333 \mathrm{mg} / \mathrm{kg})$ of test compound per larvae, $10 \%$ of the larvae treated with the metal complexes survived, whilst all of the larvae injected at this concentration with phen died. The Mn(II) complexes, 1, 3, and 7, and the $\mathrm{Cu}(\mathrm{II})$ complex, 2, all showed a marked improvement in survival observed upon decreasing the inoculant concentration to $0.02 \mathrm{mg}(67 \mathrm{mg} / \mathrm{kg})$. There were no fatalities when $0.01 \mathrm{mg}(33 \mathrm{mg} / \mathrm{kg}$ ) of the test compounds were dispensed. When assessing the relative toxicity of the test complexes an important consideration is the number of phen ligands each complex contains. From Table 3 it is apparent that the toxicity order, when normalized to the number of phen ligands per complex, is essentially unaltered.

\section{DISCUSSION}

Although the two mycobacterial strains, H37Rv and CDC1551, are equally virulent (Manca et al., 1999) the latter strain is known to induce a more rapid and robust host response in 
TABLE 1 | In vitro MIC values against two strains of M. tuberculosis (H37Rv and CDC1551), IC 50 values for VERO and A549 epithelial cells and calculated SI values for the test complexes and uncoordinated phen.

\begin{tabular}{|c|c|c|c|c|c|c|c|c|}
\hline \multirow[t]{2}{*}{ Compound } & \multicolumn{3}{|c|}{ M. tuberculosis H37Rv } & \multicolumn{3}{|c|}{ M. tuberculosis CDC1551 } & \multicolumn{2}{|c|}{ Cytotoxicity } \\
\hline & $\begin{array}{c}\mathrm{MIC}_{90} \\
\mathrm{mg} / \mathrm{L}(\mu \mathrm{M})\end{array}$ & $\begin{array}{c}\text { SI } \\
\text { VERO }\end{array}$ & $\begin{array}{c}\text { SI } \\
\text { A549 }\end{array}$ & $\begin{array}{c}\mathrm{MIC}_{100} \\
\mathrm{mg} / \mathrm{L}(\mu \mathrm{M})\end{array}$ & $\begin{array}{c}\text { SI } \\
\text { VERO }\end{array}$ & $\begin{array}{c}\text { SI } \\
\text { A549 }\end{array}$ & $\begin{array}{c}\mathrm{IC}_{50} \\
\mathrm{mg} / \mathrm{L}(\mu \mathrm{M}) \text { VERO } \\
\text { cells }\end{array}$ & $\begin{array}{c}\mathrm{IC}_{50} \\
\mathrm{mg} / \mathrm{L}(\mu \mathrm{M}) \mathrm{A549} \\
\text { cells }\end{array}$ \\
\hline Isoniazid (INH) & $0.06(0.44)$ & 5513 & 5284 & $0.06(0.44)$ & 5513 & 5284 & 332.7 (2426) & 318.9 (2325) \\
\hline 1,10-phenanthroline (phen) & $11.16(61.93)$ & 1 & 0.39 & $3.0(16.65)$ & 3 & 1.43 & $>10(>55.49)$ & $4.30(23.9)$ \\
\hline $\begin{array}{l}{\left[\mathrm{Mn}_{2}(\text { oda })(\text { phen })_{4}\left(\mathrm{H}_{2} \mathrm{O}\right)_{2}\right]} \\
{\left[\mathrm{Mn}_{2}(\text { oda })(\text { phen })_{4}\right.} \\
\left.(\text { oda })_{2}\right] \cdot 4 \mathrm{H}_{2} \mathrm{O}(\mathbf{1})\end{array}$ & $1.15(0.47)$ & 325 & 445 & $0.38(0.15)$ & 1017 & 1347 & 375 (152.55) & $>512(>208.3)$ \\
\hline $\begin{array}{l}{\left[\mathrm{Cu}_{2}(\mathrm{oda})(\text { phen })_{4}\right]\left(\mathrm{ClO}_{4}\right)_{2} \cdot} \\
2.76 \mathrm{H}_{2} \mathrm{O} \cdot \mathrm{EtOH}(\mathbf{2})\end{array}$ & $16.60(12.68)$ & 0.71 & 0.06 & $1.50(1.15)$ & 8 & 0.65 & 11.7 (8.94) & $0.98(74.9)$ \\
\hline $\begin{array}{l}\left\{\left[\mathrm{Mn}(3,6,9-\mathrm{tdda})(\text { phen })_{2}\right]\right. \\
\left.\cdot 3 \mathrm{H}_{2} \mathrm{O} \cdot \mathrm{EtOH}\right\}_{\mathrm{n}}(\mathbf{3})\end{array}$ & $0.56(0.76)$ & 112 & 467 & $0.75(1.02)$ & 83 & 349 & 62.5 (84.96) & 261.67 (355.70) \\
\hline $\begin{array}{l}\{[\mathrm{Cu}(3,6,9- \\
\left.\left.\text { tdda)(phen) })_{2}\right] \cdot 3 \mathrm{H}_{2} \mathrm{O} \cdot \mathrm{EtOH}\right\}_{n}(\mathbf{4})\end{array}$ & $10.03(13.48)$ & 0.58 & 0.11 & $0.75(1.01)$ & 8 & 1.41 & $5.85(7.86)$ & $1.06(1.42)$ \\
\hline$\left[\mathrm{Mn}(\mathrm{ph})(\mathrm{phen})\left(\mathrm{H}_{2} \mathrm{O}\right)_{2}\right](\mathbf{5})$ & $0.57(1.31)$ & 27 & 411 & $<0.19(<0.44)$ & $>82$ & 1234 & $15.6(35.84)$ & $234.51(538.73)$ \\
\hline$\left[\mathrm{Mn}(\mathrm{ph})(\text { phen })_{2}\left(\mathrm{H}_{2} \mathrm{O}\right)\right] \cdot 4 \mathrm{H}_{2} \mathrm{O}(\mathbf{6})$ & $1.42(2.12)$ & 8 & 183 & $0.38(0.57)$ & 31 & 682 & $11.7(17.47)$ & 259.34 (387.33) \\
\hline$\left[\mathrm{Mn}_{2}(\text { isoph })_{2}(\text { phen })_{3}\right] \cdot 4 \mathrm{H}_{2} \mathrm{O}(\mathbf{7})$ & $1.56(1.48)$ & 80 & 164 & $<0.19(<0.18)$ & $>661$ & 1347 & $125(118.95)$ & $255.87(243.50)$ \\
\hline $\begin{array}{l}\left.\left\{\left[\mathrm{Mn}(\text { phen })_{2}\left(\mathrm{H}_{2} \mathrm{O}\right)_{2}\right]\right\}_{2} \text { (isoph) }\right)_{2} \\
\text { (phen) } 12 \mathrm{H}_{2} \mathrm{O}(\mathbf{8})\end{array}$ & $3.01(1.85)$ & 16 & 84 & $<0.19(<0.12)$ & $>240$ & 1325 & 46.9 (28.82) & $251.76(154.70)$ \\
\hline$\left[\mathrm{Mn}(\text { tereph)(phen) })_{2}\right] \cdot 5 \mathrm{H}_{2} \mathrm{O}(\mathbf{9})$ & $3.41(5.09)$ & 14 & 74 & $0.38(0.57)$ & 123 & 663 & 46.9 (70.05) & 251.94 (376.28) \\
\hline $\begin{array}{l}\mathrm{MnCl}_{2} \cdot 2 \mathrm{H}_{2} \mathrm{O} \text { (Oliveira et al., } \\
2014)\end{array}$ & $>50(>154)$ & $<3.7$ & $<6.2$ & $\mathrm{Nt}$ & NA & NA & $92.1(568.7)$ & 153.4 (947.3) \\
\hline
\end{tabular}

Included are the MIC values for $\mathrm{MnCl}_{2} \cdot 2 \mathrm{H}_{2} \mathrm{O}$ (Oliveira et al., 2014). Selectivity Index (SI) $=\left(\mathrm{CC}_{50} / \mathrm{MIC}\right)$; Nt, not tested; NA, not applicable.

a mouse-infected model. The seven $\mathrm{Mn}(\mathrm{II})$ complexes were more active against the $\mathrm{H} 37 \mathrm{Rv}$ strain than the two $\mathrm{Cu}(\mathrm{II})$ samples, but this inequality was less pronounced against the CDC1551 strain, probably due to difference at media culture. Previous studies involving the fungal pathogen, Candida albicans, revealed that the dicarboxylic acids alone were not bioactive (Devereux et al., 2000). This finding, coupled with the fact that the current $\mathrm{Mn}$ (II) phen/dicarboxylate complexes are 30-328 times more active against $\mathrm{H} 37 \mathrm{Rv}$ than $\mathrm{MnCl}_{2} \cdot 2 \mathrm{H}_{2} \mathrm{O}$ and also show 12-132 times greater activity than phen alone (Table 1), suggests the existence of a positive synergism between the $\mathrm{Mn}(\mathrm{II})$ dication and its original phen/dicarboxylate ligand set.

The low MIC values for $\left.\left[\mathrm{Mn}_{2} \text { (oda)(phen }\right)_{4}\left(\mathrm{H}_{2} \mathrm{O}\right)_{2}\right]$ $\left.\left[\mathrm{Mn}_{2} \text { (oda)(phen }\right)_{4}(\text { oda })_{2}\right] \cdot 4 \mathrm{H}_{2} \mathrm{O} \quad$ (1) and $\{[\mathrm{Mn}(3,6,9-$ tdda)(phen $\left.\left.)_{2}\right] \cdot 3 \mathrm{H}_{2} \mathrm{O} \cdot \mathrm{EtOH}\right\} \mathrm{n}$ (3) against $\mathrm{H} 37 \mathrm{Rv}$ translated to strikingly large selectivity index (SI) values as shown in Table 1 (325/445 and 112/467, respectively, for VERO/A549 cells). Furthermore, the 3 -fold increase in activity against CDC1551 over H37Rv for 1 elevated the SI values to 1017/1347. As the $\mathrm{Cu}(\mathrm{II})$ complexes, $\mathbf{2}$ and $\mathbf{4}$, were relatively more toxic than the $\mathrm{Mn}$ (II) complexes toward the two types of mammalian cells, this severely reduced the SI values of the $\mathrm{Cu}$ (II) complexes. The highly cytotoxic nature of $\mathbf{2}$ and $\mathbf{4}$ toward A549 cells parallels our previous findings for $\mathrm{Cu}(\mathrm{II})$ phen/diacid complexes against cancer cells (Kellett et al., 2011). The isophthalate/phen complexes, $\left[\mathrm{Mn}_{2} \text { (isoph }\right)_{2}$ (phen $\left.)_{3}\right] \cdot 4 \mathrm{H}_{2} \mathrm{O}$ (7) and $\left\{\left[\mathrm{Mn}(\text { phen })_{2}\left(\mathrm{H}_{2} \mathrm{O}\right)_{2}\right]\right\}_{2}(\text { isoph })_{2}$ (phen) $12 \mathrm{H}_{2} \mathrm{O}(\mathbf{8})$, showed highly favorable SI values for CDC1551 when referenced against
VERO/A549 cells (>661/1347 and >240/1325, respectively), and this is mainly attributable to their very low $\mathrm{MIC}_{100}$ values $(<0.18,<0.12 \mu \mathrm{M})$ against the CDC1551 strain.

Dwyer et al. (1969) reported that the Mn(II), Cu(II), Zn(II) and $\mathrm{Cd}(\mathrm{II})$ phen dicationic complexes, $\left[\mathrm{M}(\text { phen })_{2}\right]\left(\mathrm{CH}_{3} \mathrm{CO}_{2}\right)_{2}$ and $\left[\mathrm{M}(\mathrm{R} \text {-phen })_{2}\right]\left(\mathrm{CH}_{3} \mathrm{CO}_{2}\right)_{2}$, all had similar activities against $\mathrm{H} 37 \mathrm{Rv}$ with $\mathrm{MIC}$ values ranging from approximately $30 \mu \mathrm{M}$ for $\left[\mathrm{M}(\text { phen })_{2}\right]^{2+}$ to $0.1 \mu \mathrm{M}$ for $\left[\mathrm{M}\left(5-\mathrm{NO}_{2}-\text { phen }\right)_{2}\right]^{2+}$. This uniformity in activity between $\mathrm{Mn}$ (II) and $\mathrm{Cu}$ (II) contrasts somewhat to our findings, which clearly show that in the case of the phen/oda and phen/tdda ligand combinations the $\mathrm{Mn}$ (II) complexes were 27- and 18-fold more active, respectively, against H37Rv than their $\mathrm{Cu}(\mathrm{II})$ analogs. Against CDC1551, the difference between the $\mathrm{Mn}$ (II) phen/oda and $\mathrm{Cu}(\mathrm{II})$ complexes was less marked (10-fold), whilst the two phen/tdda samples showed the same activity. It is primarily the high tolerance of the mammalian cells toward the $\mathrm{Mn}$ (II) complexes, in contrast to their $\mathrm{Cu}(\mathrm{II})$ analogs, that accounts for the remarkably high SI values of the $\mathrm{Mn}$ (II) complexes. Also of relevance to the present work is a recent publication (Oliveira et al., 2014) describing the activity of a collection of water-insoluble, octahedral $\mathrm{Mn}(\mathrm{II})$ complexes of formula, $\left[\mathrm{Mn}(\text { atc- } \mathrm{R})_{2}\right]$ (atc- $\mathrm{R}=$ tridentate 2-acetylpyridine-N(4)-R-thiosemicarbazone anion), against $M$. tuberculosis H37Rv. MIC values, which were dependent on the nature of the pendant $\mathrm{R}$ group, ranged from 50.69 to $1.31 \mu \mathrm{M}$, with a corresponding SI range (measured against VERO cells) of 5.3->641 (for [ $\left.\mathrm{Mn}(\text { atc-Me })_{2}\right]$ to $\left[\mathrm{Mn}(\text { atc- } \mathrm{Ph})_{2}\right]$, respectively). On comparing the excellent and somewhat similar SI values of hydrophobic $\left[\mathrm{Mn}(\text { atc- } \mathrm{Ph})_{2}\right]$ with relatively hydrophilic 
TABLE 2 | Percentage mortality of G. mellonella larvae $72 \mathrm{~h}$ post-injection with various dosages of test compounds.

\begin{tabular}{|c|c|c|c|c|c|}
\hline \multirow[t]{2}{*}{ Compound } & \multicolumn{5}{|c|}{ Administered amount $/ \%$ Mortality $\mu \mathrm{g}$ per larvae $(\mathrm{mg} / \mathrm{kg})$} \\
\hline & & $100(333.33)$ & $40(133.33)$ & $20(66.67)$ & $10(33.33)$ \\
\hline \multirow[t]{2}{*}{ 1,10-phenanthroline (phen) ${ }^{24}$} & $\mu \mathrm{mol}$ & 0.55 & 0.22 & 0.11 & 0.06 \\
\hline & \% Mortality & $100 \%$ & $80 \%$ & $80 \%$ & $0 \%$ \\
\hline \multirow{2}{*}{$\begin{array}{l}{\left[\mathrm{Mn}_{2}(\text { oda })(\text { phen }) 4\left(\mathrm{H}_{2} \mathrm{O}\right)_{2}\right]\left[\mathrm{Mn}_{2}(\text { oda })(\text { phen })_{4}(\mathrm{oda})_{2}\right] \cdot 4 \mathrm{H}_{2} \mathrm{O}} \\
(\mathbf{1})^{24}\end{array}$} & $\mu \mathrm{mol}$ & 0.041 & 0.016 & 0.008 & 0.004 \\
\hline & \% Mortality & $90 \%$ & $90 \%$ & $40 \%$ & $0 \%$ \\
\hline \multirow[t]{2}{*}[\mathrm{Cu}_{2}(\mathrm{oda})(\text{phen})_{4}]{$\left(\mathrm{ClO}_{4}\right)_{2} \cdot 2.76 \mathrm{H}_{2} \mathrm{O} \cdot \mathrm{EtOH}(\mathbf{2})^{24}$} & $\mu \mathrm{mol}$ & 0.076 & 0.030 & 0.015 & 0.008 \\
\hline & \% Mortality & $90 \%$ & $90 \%$ & $50 \%$ & $0 \%$ \\
\hline $\multirow[t]{2}{*}{\left[\mathrm{Mn}(3,6,9-\mathrm{tdda})(\text { phen })_{2}\right] \cdot 3 \mathrm{H}_{2} \mathrm{O} \cdot \mathrm{EtOH}}_{\mathrm{n}}(\mathbf{3})$ & $\mu \mathrm{mol}$ & 0.136 & 0.056 & 0.028 & 0.014 \\
\hline & \% Mortality & $90 \%$ & $80 \%$ & $50 \%$ & $0 \%$ \\
\hline $\multirow[t]{2}{*}{\left[\mathrm{Cu}(3,6,9-\mathrm{tdda})(\text { phen })_{2}\right] \cdot 3 \mathrm{H}_{2} \mathrm{O} \cdot \mathrm{EtOH}}_{\mathrm{n}}$ (4) & $\mu \mathrm{mol}$ & 0.134 & 0.054 & 0.027 & 0.013 \\
\hline & \% Mortality & $90 \%$ & $90 \%$ & $80 \%$ & $0 \%$ \\
\hline \multirow[t]{2}{*}[\mathrm{Mn}(\mathrm{ph})(\mathrm{phen})(\mathrm{H}_{2}\mathrm{O})_{2}]{$(5)$} & $\mu \mathrm{mol}$ & 0.230 & 0.092 & 0.046 & 0.023 \\
\hline & \% Mortality & $90 \%$ & $90 \%$ & $80 \%$ & $0 \%$ \\
\hline \multirow[t]{2}{*}[\mathrm{Mn}(\mathrm{ph})(\text{phen})_{2}(\mathrm{H}_{2}\mathrm{O})]{$\cdot 4 \mathrm{H}_{2} \mathrm{O}(\mathbf{6})$} & $\mu \mathrm{mol}$ & 0.149 & 0.060 & 0.030 & 0.015 \\
\hline & \% Mortality & $90 \%$ & $90 \%$ & $80 \%$ & $0 \%$ \\
\hline $\left.\multirow[t]{2}{*}{\mathrm{Mn}_{2} \text { (isoph) }}_{2}(\text { phen })_{3}\right] \cdot 4 \mathrm{H}_{2} \mathrm{O}(\mathbf{7})$ & $\mu \mathrm{mol}$ & 0.095 & 0.040 & 0.020 & 0.010 \\
\hline & \% Mortality & $90 \%$ & $80 \%$ & $60 \%$ & $0 \%$ \\
\hline $\multirow[t]{2}{*}{\left[\mathrm{Mn}(\text { phen })_{2}\left(\mathrm{H}_{2} \mathrm{O}\right)_{2}\right]}_{2}$ (isoph) $)_{2}($ phen $) \cdot 12 \mathrm{H}_{2} \mathrm{O}(\mathbf{8})$ & $\mu \mathrm{mol}$ & 0.061 & 0.025 & 0.012 & 0.006 \\
\hline & \% Mortality & $90 \%$ & $90 \%$ & $80 \%$ & $0 \%$ \\
\hline \multirow[t]{2}{*}[\mathrm{Mn}\text{(tereph)(phen)}2]{$\cdot 5 \mathrm{H}_{2} \mathrm{O}(\mathbf{9})$} & $\mu \mathrm{mol}$ & 0.149 & 0.060 & 0.030 & 0.015 \\
\hline & \% Mortality & $90 \%$ & $90 \%$ & $80 \%$ & $0 \%$ \\
\hline
\end{tabular}

TABLE 3 | Toxicity ordering of the compounds against G. mellonella larvae when the results from Table 2 are normalized with respect to phen content.

\begin{tabular}{|c|c|c|c|c|c|c|}
\hline & $\begin{array}{l}\text { In vivo G. mellonella tolerance order in } \\
\mu \mathrm{mol}\end{array}$ & No. of phens & & $\begin{array}{l}\text { In vivo G. mellonella tolerance order in } \\
\mu \mathrm{mol} \text { (Normalized against no. of phens) }\end{array}$ & $\begin{array}{l}\text { No. of } \\
\text { phens }\end{array}$ & \\
\hline $1 \mathrm{st}$ & $\begin{array}{l}{\left[\mathrm{Mn}_{2}(\mathrm{oda})(\text { phen })_{4}\left(\mathrm{H}_{2} \mathrm{O}\right)_{2}\right]\left[\mathrm{Mn}_{2}(\text { oda })(\text { phen })_{4}(\text { oda })_{2}\right]} \\
4 \mathrm{H}_{2} \mathrm{O}(\mathbf{1})\end{array}$ & 8 & $1 s t$ & $\begin{array}{l}{\left[\mathrm{Mn}_{2}(\text { oda })(\text { phen })_{4}\left(\mathrm{H}_{2} \mathrm{O}\right)_{2}\right]\left[\mathrm{Mn}_{2}(\text { oda })(\text { phen })_{4}(\text { oda })_{2}\right]} \\
4 \mathrm{H}_{2} \mathrm{O} \text { (1) }\end{array}$ & 8 & $\begin{array}{l}\text { Highly } \\
\text { Tolerated/ } \\
\text { Least Toxic }\end{array}$ \\
\hline 2nd & $\left\{\left[\mathrm{Mn}(3,6,9-\mathrm{tdda})(\text { phen })_{2}\right] \cdot 3 \mathrm{H}_{2} \mathrm{O} \cdot \mathrm{EtOH}\right\}_{\mathrm{n}}(\mathbf{3})$ & 2 & 2nd & $\left\{\left[\mathrm{Mn}(3,6,9 \text {-tdda })(\text { phen })_{2}\right] \cdot 3 \mathrm{H}_{2} \mathrm{O} \cdot \mathrm{EtOH}\right\}_{\mathrm{n}}(\mathbf{3})$ & 2 & \\
\hline $3 r d$ & {$\left[\mathrm{Cu}_{2}(\mathrm{oda})(\text { phen })_{4}\right]\left(\mathrm{ClO}_{4}\right)_{2} \cdot 2.76 \mathrm{H}_{2} \mathrm{O} \cdot \mathrm{EtOH}(\mathbf{2})$} & 4 & 2nd & $\begin{array}{l}{\left[\mathrm{Cu}_{2}(\mathrm{oda})(\text { phen })_{4}\right]\left(\mathrm{ClO}_{4}\right)_{2} \cdot 2.76 \mathrm{H}_{2} \mathrm{O} \cdot \mathrm{EtOH}} \\
\text { (2) }\end{array}$ & 4 & \\
\hline 4th & {$\left[\mathrm{Mn}_{2}(\text { isoph })_{2}(\text { phen })_{3}\right] \cdot 4 \mathrm{H}_{2} \mathrm{O}(\mathbf{7})$} & 3 & 3rd & {$\left[\mathrm{Mn}_{2}(\text { isoph })_{2}(\text { phen })_{3}\right] \cdot 4 \mathrm{H}_{2} \mathrm{O}(\mathbf{7})$} & 3 & \\
\hline 5th & 1,10-phenanthroline (phen) & 1 & 4th & 1,10-phenanthroline (phen) & 1 & \\
\hline 6th & {$\left[\mathrm{Mn}(\mathrm{ph})(\mathrm{phen})\left(\mathrm{H}_{2} \mathrm{O}\right)_{2}\right](\mathbf{5})$} & 1 & 5th & {$\left[\mathrm{Mn}(\mathrm{ph})(\text { phen })_{2}\left(\mathrm{H}_{2} \mathrm{O}\right)\right] \cdot 4 \mathrm{H}_{2} \mathrm{O}(\mathbf{6})$} & 2 & \\
\hline 7th & {$\left[\mathrm{Mn}(\mathrm{ph})(\text { phen })_{2}\left(\mathrm{H}_{2} \mathrm{O}\right)\right] \cdot 4 \mathrm{H}_{2} \mathrm{O}(\mathbf{6})$} & 2 & 5th & $\begin{array}{l}\left\{\left[\mathrm{Mn}(\text { phen })_{2}\left(\mathrm{H}_{2} \mathrm{O}\right)_{2}\right]\right\}_{2}(\text { isoph })_{2}(\text { phen }) \cdot 12 \mathrm{H}_{2} \mathrm{O} \\
(\mathbf{8})\end{array}$ & 5 & \\
\hline 7th & {$\left[\mathrm{Mn}(\text { tereph)(phen) })_{2}\right] \cdot 5 \mathrm{H}_{2} \mathrm{O}(\mathbf{9})$} & 2 & 5th & {$\left[\mathrm{Mn}(\text { tereph)(phen) })_{2}\right] \cdot 5 \mathrm{H}_{2} \mathrm{O}(\mathbf{9})$} & 2 & $\begin{array}{l}\text { Least } \\
\text { Tolerated/ }\end{array}$ \\
\hline 8th & $\left\{\left[\mathrm{Cu}(3,6,9-\mathrm{tdda})(\text { phen })_{2}\right] \cdot 3 \mathrm{H}_{2} \mathrm{O} \cdot \mathrm{EtOH}\right\}_{\mathrm{n}}(\mathbf{4})$ & 2 & 6th & $\left\{\left[\mathrm{Cu}(3,6,9-\mathrm{tdda})(\text { phen })_{2}\right] \cdot 3 \mathrm{H}_{2} \mathrm{O} \cdot \mathrm{EtOH}\right\}_{\mathrm{n}}(\mathbf{4})$ & 2 & Most Toxic \\
\hline 9th & $\left\{\left[\mathrm{Mn}(\text { phen })_{2}\left(\mathrm{H}_{2} \mathrm{O}\right)_{2}\right]\right\}_{2}$ (isoph) $)_{2}$ (phen) $\cdot 12 \mathrm{H}_{2} \mathrm{O}(\mathbf{8})$ & 5 & 6th & {$\left[\mathrm{Mn}(\mathrm{ph})(\right.$ phen $\left.)\left(\mathrm{H}_{2} \mathrm{O}\right)_{2}\right](\mathbf{5})$} & 1 & \\
\hline
\end{tabular}

$\left.\left.\left[\mathrm{Mn}_{2} \text { (oda) (phen }\right)_{4}\left(\mathrm{H}_{2} \mathrm{O}\right)_{2}\right]\left[\mathrm{Mn}_{2} \text { (oda) (phen }\right)_{4}(\text { oda })_{2}\right] \cdot 4 \mathrm{H}_{2} \mathrm{O}$ (1), it is the very high $\mathrm{IC}_{50}$ value for $\left[\mathrm{Mn}(\text { atc- } \mathrm{Ph})_{2}\right]$ that is the dominant feature, whilst for $\mathbf{1}$ the major contributing factor is the extremely low MIC value.

Whilst relatively small quantities of transition metal ions (primarily $\mathrm{Mn}, \mathrm{Fe}, \mathrm{Co}, \mathrm{Ni}, \mathrm{Cu}, \mathrm{Zn}$ ) are essential micronutrients for sustaining microbial growth and homeostasis (Braymer and Giedroc, 2014; Neyrolles et al., 2015), exposure to high concentrations can be devastating as they can bind to and disable important biomolecules and/or promote oxidative stress through Fenton chemistry. It is important to note that $\mathrm{Mn}$ (II) and $\mathrm{Cu}(\mathrm{II})$ complexes are kinetically labile, meaning that they can rapidly exchange their original ligands (phen and dicarboxylate in the present cases) for other donor ligands present in a biological milieu which includes the bacterium itself. Thus, it is anticipated that a dynamic equilibrium is rapidly established between the original M(II)-phen/dicarboxylate and the newly formed various $\mathrm{M}(\mathrm{II})$-bioligand complexes. 
There are several potential explanations for the superior activity of the $\mathrm{Mn}$ (II) phen/dicarboxylates $\mathbf{1}$ and $\mathbf{3}$ against M. tuberculosis $\mathrm{H} 37 \mathrm{Rv}$ relative to their $\mathrm{Cu}(\mathrm{II})$ equivalents, 2 and 4. Various metal dication transporter proteins have been identified for M. tuberculosis, which includes CTR1 for $\mathrm{Cu}(\mathrm{II})$, [(Manca et al., 1999) multimetal Mramp (Mn(II), Fe(II), Cu(II) and $\mathrm{Zn}(\mathrm{II})]$ (Agranoff et al., 1999) and a fleet of $\mathrm{P}_{1 \mathrm{~B}}$-ATPases for $\mathrm{Mn}(\mathrm{II}), \mathrm{Cu}(\mathrm{II})$ and some other metals (Padilla-Benavides et al., 2013). It is known that $\mathrm{Cu}(\mathrm{II})$ must be reduced to $\mathrm{Cu}(\mathrm{I})$, possibly by membrane associated copper reductases (Hassett and Kosman, 1995), before being recruited by the $\mathrm{Cu}(\mathrm{I})$ importer protein, CTR1. On the other hand, metallothioneins present in the bacterial cytosol prevent copper overload and toxicity by sequestering surplus copper ions (Wang et al., 2011). In addition, the copper transporter protein, ATP7A, can translocate to the plasma membrane and pump excess copper out of the cell (Petris and Mercer, 1999). The outer membrane channel protein, Rv1698, of $M$. tuberculosis is also reported to efflux excess $\mathrm{Cu}$ (II) from the mycobacterial cell envelope, a process which is necessary for its survival (Wolschendorf et al., 2011). Likewise, the membrane protein, MctB, reduces intracellular copper levels and is required for full $M$. tuberculosis copper resistance and virulence in mice and guinea pigs (Wolschendorf et al., 2011). It may be an inability to reduce administered $\mathrm{Cu}$ (II) to $\mathrm{Cu}(\mathrm{I})$ and/or sequestration and efflux that is managing to buffer the amount of $\mathrm{Cu}$ (II) to the relatively non-hazardous levels observed for the current $\mathrm{Cu}(\mathrm{II})$ complexes against $\mathrm{H} 37 \mathrm{Rv}$ in comparison to their $\mathrm{Mn}(\mathrm{II})$ analogs.

Recent research has shown that $M$. tuberculosis may be highly susceptible to specific types of reactive oxygen species (ROS) and reactive nitrogen species (RNS) (Cirillo et al., 2009; Voskuil et al., 2011; Roca and Ramakrishnan, 2013; Vilcheze et al., 2013), and the bacteria releases a defensive brigade of enzymes/proteins to counteract the oxidative and nitrosative onslaught by mammalian host cells (Kim et al., 2012). Whilst nitric oxide (NO) has a bacteriostatic effect on M. tuberculosis $\mathrm{H}_{2} \mathrm{O}_{2}$ is not bacteriostatic at concentrations below $50 \mathrm{mM}$, but above this concentration the peroxide is bactericidal (Voskuil et al., 2011). Thus, it would appear that M. tuberculosis cells are not equally or universally susceptibility to ROS or RNS and that this may help explain the superior growth inhibitory effects exhibited by the $\mathrm{Mn}$ (II)-based test complexes over the $\mathrm{Cu}$ (II) complexes, especially against the H37Rv strain. Complex $\mathbf{1}$ is an avid generator of intracellular ROS (Kellett et al., 2011) and its strong anti-mycobacterial activity may be due to the type and quantity of free radicals or ROS/RNS (superoxide $\mathrm{O}_{2} \cdot{ }^{-}$, hydroxyl radical $\cdot \mathrm{OH}, \cdot \mathrm{NO})$ that the $\mathrm{Mn}(\mathrm{II})$ complexes produce. It is conceivable that $\mathbf{1}$ is generating higher levels of $\mathrm{O}_{2} \cdot{ }^{-}, \cdot \mathrm{NO}$ and $\mathrm{H}_{2} \mathrm{O}_{2}$ than its $\mathrm{Cu}$ (II)-based analog, 2. In addition, the production of extremely destructive $\cdot \mathrm{OH}$ radicals by $\mathbf{1}$ may also account for its high anti-mycobacterial activity, as well as that of all of the test $\mathrm{Mn}$ (II) complexes. If this is indeed the mode of action of these $\mathrm{Mn}$ (II) complexes, then they could possibly overwhelm any strain with acquired resistance to INH. INH is a prodrug and is oxidized by a bacterial catalase-peroxidase enzyme (KatG) present in $M$. tuberculosis, forming an isonicotinic acyl moiety (either an acyl radical or acyl anion). The acyl moiety forms a strong covalent bond to the nicotinamide ring of the nicotinamide adenine dinucleotide cation $\left(\mathrm{NAD}^{+}\right)$, and this acyl-NAD entity docks into the active site of the enoyl-acyl carrier protein reductase, InhA, the enzyme which mediates fatty acid synthesis (Dessen et al., 1995; Zabinski and Blanchard, 1997; Rozwarski et al., 1998; Oliveira et al., 2014). Fatty acids are required for the subsequent production of mycolic acid, which is a key component of the mycobacterial cell wall. Thus, INH indirectly blocks bacterial cell wall construction, leading to the demise of the organism. INH resistance is frequently associated with KatG structural gene alterations, resulting in KatG mutant enzymes with reduced ability to form activated INH compounds (Jagielski et al., 2014). Both KatG and Mn complexes/ions are able to oxidize INH and form the active isonicotinoyl-NAD adduct (Magliozzo and Marcinkeviciene, 1997; Oliveira et al., 2014; Viganor et al., 2015). Also of note is that M. smegmatis, a closely related but nonpathogenic bacterium, contains a variant of KatG which has been shown to require $\mathrm{Mn}(\mathrm{II})$ ions for activation of $\mathrm{INH}$, possibly via oxidation of $\mathrm{Mn}$ (II) to $\mathrm{Mn}(\mathrm{III})$ which in turn oxidizes INH (Magliozzo and Marcinkeviciene, 1997). Conversely, Mn(II) ions are not essential for $M$. tuberculosis KatG-mediated oxidative activation of INH although the addition of exogenous Mn(II) ions has been shown to enhance the activation of INH by wildtype and various mutants of M. tuberculosis KatG (Lei et al., 2000; Wei et al., 2003). Interestingly, INH-resistant clinical isolates of $M$. tuberculosis have a high incidence of a mutant variant of the KatG enzyme, namely KatG S315, in which the replacement of a serine residue at position 315 in the catalytic domain results in the inability to oxidize INH to isonicotinic acid (Wei et al., 2003; Jagielski et al., 2014). The ability to oxidize INH can be restored to wild-type KatG S315 mutants and other KatG variants (obtained via site directed mutagenesis) by the addition of $\mathrm{Mn}$ (II) ions (Lei et al., 2000; Wei et al., 2003). M. smegmatis cells, unlike most strains of $M$. tuberculosis, are intrinsically highly resistant to INH ( $\mathrm{MIC}>30 \mathrm{mg} / \mathrm{mL} ;>218.76 \mathrm{mM}$ ), a feature which may be due, in part, to the low levels of $\mathrm{Mn}$ (II) ions present in M. smegmatis cells in vivo (Wei et al., 2003). Therefore, co-administration of INH with the current $\mathrm{Mn}$ (II)-based complexes could result in the metal complex acting as an alternative oxidant, mimicking the activity of KatG and thus providing a non-enzymatic oxidation and consequent activation of INH, whilst also independently expressing its ROS-mediated growth inhibitory effect on the bacteria. Investigating a possible positive synergism between the Mn(II) complexes and INH will be the focus of a future investigation by our research network.

Encouragingly, all of the metal complexes appear to be welltolerated, in vivo, by G. mellonella larvae (Tables 2 3). These data suggest that the relative in vivo toxicity profile of the metal complexes is not dependent on the number of coordinated phen ligands present per complex. In addition, regarding the nuclearity (mononuclear, binuclear, tetranuclear) of the metal complexes, there does not appear to be an increase in toxicity upon increasing the metal content of the complex. For example, the tetra-Mn(II) complex $\mathbf{1}$ is much less toxic toward G. mellonella than the mono-Mn(II) complex 9. Similarly, the di-Cu(II) species 2 is better tolerated than mono-Cu(II) 4. Although $\mathrm{Mn}(\mathrm{II})$ and $\mathrm{Cu}$ (II) complexes are inherently liable, comparisons based on 
phen and metal content of the complexes suggest that it is the complex as a whole, rather than the individual components of the complexes, that are responsible for the observed effects on the larvae.

\section{CONCLUSION}

In conclusion, $\mathrm{Mn}$ (II) phen/dicarboxylate complexes, which can be synthesized efficiently, utilizing economical and readily available starting materials, offer realistic promise as effective, selective and safe lead candidates in the search for new drugs for the treatment of TB.

\section{AUTHOR CONTRIBUTIONS}

PM, MM, MD, KK, CS, PK, AA, TM, AS, DC, and FP conceived and designed the study. PM, MM, AS, and FP analyzed the

\section{REFERENCES}

Agranoff, D., Monahan, I. M., Mangan, J. A., Butcher, P. D., and Krishna, S. (1999). Mycobacterium tuberculosis expresses a novel $\mathrm{pH}$-dependent divalent cation transporter belonging to the Nramp family. J Exp Med. 190, 717-724. doi: 10.1084/jem.190.5.717

Bennett, D. R. (1994). “Antimycobacterial drugs," in Drug Evaluations Annual, Wiley, NJ: American Medical Association, 1627-1657.

Bernardes-Génisson, V., Deraeve, C., Chollet, A., Bernadou, J., and Pratviel, G. (2013). Isoniazid: an update on the multiple mechanisms for a singular action. Curr Med Chem. 20, 4370-4385. doi: 10.2174/15672050113109990203

Braymer, J. J., and Giedroc, D. P. (2014). Recent developments in copper and zinc homeostasis in bacterial pathogens. Curr. Opin. Chem. Biol. 19, 59-66. doi: 10.1016/j.cbpa.2013.12.021

Cirillo, S. L. G., Subbian, S., Chen, B., Weisbrod, T. R., Jacobs, W. R., and Cirillo, J. D. (2009). Protection of Mycobacterium tuberculosis from reactive oxygen species conferred by the mel2 locus impacts persistence and dissemination. Infect Immun. 77, 2557-2567. doi: 10.1128/IAI.01481-08

Cole, S. T., Brosch, R., Parkhill, J., Garnier, T., Churcher, C., Harris, D., et al. (1998). Deciphering the biology of Mycobacterium tuberculosis from the complete genome sequence. Nature 393, 537-544. doi: 10.1038/31159

Dabrowiak, J. C. (2009). Metals in Medicine. Chippenham, UK: Wiley.

Desbois, A. P., and Coote, P. J. (2012). Utility of greater wax moth larva (Galleria mellonella) for evaluating the toxicity and efficacy of new antimicrobial agents. Adv. Appl. Microbiol. 78: 25-53. doi: 10.1016/B978-0-12-394805-2.00002-6

Dessen, A., Quemard, A., Blanchard, J. S., Jacobs, W. R., and Sacchettini, J. C. (1995). Crystal structure and function of the isoniazid target of Mycobacterium tuberculosis. Science 267, 1638-1641. doi: 10.1126/science.7886450

Devereux, M., McCann, M., Leon, V., Geraghty, M., McKee, V., and Wikaira, J. (2000). Synthesis and biological activity of manganese (II) complexes of phthalic and isophthalic acid: X-ray crystal structures of $\left[\mathrm{Mn}(\mathrm{ph})(\mathrm{Phen})_{2}\left(\mathrm{H}_{2} \mathrm{O}\right)\right] \cdot 4 \mathrm{H}_{2} \mathrm{O}, \quad\left[\mathrm{Mn}(\mathrm{Phen})_{2}\left(\mathrm{H}_{2} \mathrm{O}\right)_{2}\right]_{2}$ (Isoph $)_{2}(\mathrm{Phen}) \cdot 12 \mathrm{H}_{2} \mathrm{O}$ and $\left\{[\mathrm{Mn}(\mathrm{Isoph})(\text { bipy })]_{4} \cdot 2.75\right.$ biby $\} \mathrm{n} \quad\left(\mathrm{phH}_{2}=\right.$ phthalic Acid; isoph = isophthalic Acid; phen =1,10-phenanthroline; bipy = 2,2-bipyridine). MetalBased Drugs 7, 275-288. doi: 10.1155/MBD.2000.275

Dholariya, H. R., Patel, K. S., Patel, J. C., and Patel, K. D. (2013). Dicoumarol complexes of $\mathrm{Cu}(\mathrm{II})$ based on 1,10-phenanthroline: Synthesis, X-ray diffraction studies, thermal behavior and biological evaluation. Spectrochim. Acta Part Mol. Biomol. Spectrosc. 108, 319-328. doi: 10.1016/j.saa.2012.09.096

Dwyer, F. P., Reid, I. K., Shulman, A., Laycock, G. M., and Dixson, S. (1969). The biological actions of 1,10-phenanthroline and 2,2'-bipyridine hydrochlorides quaternary salts and metal chelates and related compounds. 1. Bacteriostatic action on selected gram-positive gram-negative and acid-fast bacteria. Austr. J. Exp. Biol. Med. Sci. 47, 203-218. doi: 10.1038/icb.1969.21 data and wrote the manuscript. All authors approved of the manuscript.

\section{FUNDING}

This work was supported by National Institute of Health (grant numbers R01AI083125 and R01HL106786) to PK and also by Brazilian agencies Fundacao de Amparo à Pesquisa no Estado do Rio de Janeiro (FAPERJ) and Estado de São Paulo (FAPESP) (grant 2013/14957-5), Conselho Nacional de Desenvolvimento Cientifico e Tecnologico (CNPq) and Coordenação de Aperfeiçoamento de Pessoal de Nível Superior (CAPES). PM would like to acknowledge the funding received through Dublin Institute of Technology's Arnold F. Graves Postdoctoral Fellowship scheme. Programa de Apoio ao Desenvolvimento Científico da Faculdade de Ciências Farmacêuticas da Unesp-PADC.

Gandra, R. M., Mc Carron, P., Fernandes, M. F., Ramos, L. S., Mello, T. P., Aor, A. C., et al. (2017). Antifungal potential of copper(II), manganese(II) and silver(I) 1,10-phenanthroline chelates against multidrug-resistant fungal species forming the Candida haemulonii complex: impact on the planktonic and biofilm lifestyles. Front Microbiol. 8:1257. doi: 10.3389/fmicb.2017.01257

Gielen, M., and Tiekink, E. R. T. (2005). Metallotherapeutic Drugs and Metal-Based Diagnostic Agents. The Uses of Metals in Medicine. Padstow, UK: Wiley.

Hassett, R., and Kosman, D. J. (1995). Evidence for $\mathrm{Cu}(\mathrm{II})$ reduction as a component of copper uptake by Saccharomyces cerevisiae. J. Biol. Chem. 270, 128-134. doi: 10.1074/jbc.270.1.128

Hoffman, A. E., De Stefano, M., Shoen, C., Gopinath, K., Warner, D. F., Cynamon, M., et al. (2013). Co(II) and $\mathrm{Cu}(\mathrm{II})$ pyrophosphate complexes have selectivity and potency against Mycobacteria including Mycobacterium tuberculosis. Eur. J. Med. Chem. 70, 589-593. doi: 10.1016/j.ejmech.2013.10.044

Jagielski, T., Bakula, Z., Roeske, K., Kaminski, M., Napiorkowska, A., Augustynowicz-Kopec, E., et al. (2014). Detection of mutations associated with isoniazid resistance in multidrug-resistant Mycobacterium tuberculosis clinical isolates. J. Antimicrob. Chemother. 69, 2369-2375. doi: 10.1093/jac/dku161

Kellett, A., O'Connor, M., McCann, M., Howe, O., Casey, A., McCarron, P., et al. (2011). Water-soluble bis(1,10-phenanthroline) octanedioate $\mathrm{Cu}^{2+}$ and $\mathrm{Mn}^{2+}$ complexes with unprecedented nano and picomolar in vitro cytotoxicity: promising leads for chemotherapeutic drug development. MedChemComm. 2, 579-584. doi: 10.1039/c0md00266f

Kim, K. H., An, D. R., Song, J., Yoon, J. Y., Kim, H. S., Yoon, H. J., et al. (2012). Mycobacterium tuberculosis Eis protein initiates suppression of host immune responses by acetylation of DUSP16/MKP-7. Proc. Natl. Acad. Sci. U.S.A. 109, 7729-7734. doi: 10.1073/pnas.1120251109

Krishnan, N., Robertson, B. D., and Thwaites, G. (2010). The mechanisms and consequences of the extra-pulmonary dissemination of Mycobacterium tuberculosis. Tuberculosis 90, 361-366. doi: 10.1016/j.tube.2010.08.005

Landsdown, A. B. G. (2010). Silver in Healthcare: Its Antimicrobial, Efficacy and Safety in Use. Cambridge, UK: Royal Society of Chemistry.

Lei, B. F., Wei, C. J., and Tu, S. C. (2000). Action mechanism of antitubercular isoniazid - activation Mycobacterium tuberculosis KatG, isolation, and characterization of InhA inhibitor. J. Biol. Chem. 275, 2520-2526. doi: 10.1074/jbc.275.4.2520

Magliozzo, R. S., and Marcinkeviciene, J. A. (1997). The role of Mn(II)peroxidase activity of mycobacterial catalase-peroxidase in activation of the antibiotic isoniazid. J. Biol Chem. 272, 8867-8870. doi: 10.1074/jbc.272. 14.8867

Manca, C., Tsenova, L., Barry, C. E., Bergtold, A., Freeman, S., Haslett, P. A., et al., (1999). Mycobacterium tuberculosis CDC induces a more vigorous host response in vivo and in vitro, but is not more virulent than other clinical isolates. J. Immunol. 162, 6740-6746. 
McCann, M., Santos, A. L. S., Silva, B. A., Romanos, M. T. V., Pyrrho, A. S., Devereux, M., et al. (2012). In vitro and in vivo studies into the biological activities of 1,10-phenanthroline, 1,10-phenanthroline-5,6dione and its copper(II) and silver(I) complexes. Toxicol Res. 1, 47-54. doi: 10.1039/c2tx00010e

Mjos, K. D., and Orvig, C. (2014). Metallodrugs in Medicinal Inorganic Chemistry. Chem. Rev. 114, 4540-4563. doi: 10.1021/cr400460s

Neyrolles, O., Wolschendorf, F., Mitra, A., and Niederweis, M. (2015). Mycobacteria, metals, and the macrophage. Immunol. Rev. 264, 249-263. doi: 10.1111/imr.12265

Oliveira, C. G., Maia, P. I., Souza, P. C., Pavan, F. R., Leite, C. Q., Viana, R. B., et al. (2014). Manganese(II) complexes with thiosemicarbazones as potential anti-Mycobacterium tuberculosis agents. J. Inorg. Biochem. 132, 21-29. doi: 10.1016/j.jinorgbio.2013.10.011

Oliveira, J. S., Sousa, E. H. S., Basso, L. A., Palaci, M., Dietze, R., Santos, D. S., et al. (2004). An inorganic iron complex that inhibits wild-type and an isoniazidresistant mutant 2-trans-enoyl-ACP (CoA) reductase from Mycobacterium tuberculosis. Chem. Commun. 7, 312-313. doi: 10.1039/b313592f

Padilla-Benavides, T., Long, J. E., Raimunda, D., Sassetti, C. M., and Arguello, J. M. (2013). A novel P(1B)-type $\mathrm{Mn}^{2+}$-transporting ATPase is required for secreted protein metallation in mycobacteria. J Biol Chem. 288, 11334-11347. doi: 10.1074/jbc.M112.448175

Palomino, J. C., Martin, A., Camacho, M., Guerra, H., Swings, J., and Portaels, F. (2002). Resazurin microtiter assay plate: simple and inexpensive method for detection of drug resistance in Mycobacterium tuberculosis. Antimicrob Agents Chemother. 46, 2720-2722. doi: 10.1128/AAC.46.8.2720-2722.2002

Patel, J. C., Dholariya, H. R., Patel, K. S., and Patel, K. D. (2012). Spectral, thermal, biological and multi-heating rate kinetic properties of $\mathrm{Cu}(\mathrm{II})$ complexes containing $\mathrm{N}_{2} \mathrm{O}_{2}$ donor ligands: 1,10-phenanthroline and acyl coumarins. Appl. Organometal. Chem. 26, 604-613. doi: 10.1002/aoc.2907

Pavan, F. R., Maia, P. I. D., Leite, S. R. A., Deflon, V. M., Batista, A. A., Sato, D. N., et al. (2010). Thiosemicarbazones, semicarbazones, dithiocarbazates and hydrazide/hydrazones: anti-Mycobacterium tuberculosis activity and cytotoxicity. Eur. J. Med. Chem. 45, 1898-1905. doi: 10.1016/j.ejmech.2010.01.028

Petris, M. J., and Mercer, J. F. B. (1999). The Menkes protein (ATP7A; MNK) cycles via the plasma membrane both in basal and elevated extracellular copper using a C-terminal di-leucine endocytic signal. Human Mol. Gens. 8, 2107-2115. doi: $10.1093 / \mathrm{hmg} / 8.11 .2107$

Poggi, M., Barroso, R., Costa, A. J., de Barros, H. B., Pavan, F., Leite, C. Q., et al. (2013). New isoniazid complexes, promising agents against Mycobacterium tuberculosis. J. Mex. Chem. Soc. 57, 198-204. doi: 10.29356/jmcs.v57i3.207

Roca, F. J., and Ramakrishnan, L. (2013). TNF dually mediates resistance and susceptibility to mycobacteria via mitochondrial reactive oxygen species. Cell 153, 521-534. doi: 10.1016/j.cell.2013.03.022

Rozwarski, D. A., Grant, G. A., Barton, D. H. R., Jacobs, W. R., and Sacchettini, J. C. (1998). Modification of the NADH of the Isoniazid Target (InhA) from Mycobacterium tuberculosis. Science 279, 98-102. doi: 10.1126/science.279. 5347.98
Ryan, K., Ray, C. G., Ahmad, N., Drew, W. L., and Plorde, J. (2014). Sherris Medical Microbiology, 6th Edn. New York, NY: McGraw-Hill Education.

Segura, D. F., Netto, A. V. G., Frem, R. C. G., Mauro, A. E., da Silva, P. B., Fernandes, J. A., et al. (2014). Synthesis and biological evaluation of ternary silver compounds bearing N,N-chelating ligands and thiourea: X-ray structure of $\{\mathrm{Ag}(\mathrm{bpy})(\mu-\mathrm{tu})\}_{2}\left(\mathrm{NO}_{3}\right)_{2}\left(\mathrm{bpy}=2,2^{\prime}\right.$-bipyridine; tu = thiourea). Polyhedron 79, 197-206. doi: 10.1016/j.poly.2014.05.004

Stobie, N., Duffy, B., McCormack, D., Colreavy, J., Hidalgo, M., McHale, P., et al. (2008). Prevention of staphylococcus epidermidis biofilm formation using a low-temperature processed silver-doped phenyltriethoxysilane sol-gel coating. Biomaterials 29, 963-969. doi: 10.1016/j.biomaterials.2007.10.057

Viganor, L., Skerry, C., McCann, M., and Devereux, M. (2015). Tuberculosis: an inorganic medicinal chemistry perspective. Curr. Med. Chem. 22, 2199-2224. doi: 10.2174/0929867322666150408112357

Vilcheze, C., Hartman, T., Weinrick, B., and Jacobs, W. R. (2013). Mycobacterium tuberculosis is extraordinarily sensitive to killing by a vitamin C-induced Fenton reaction. Nat. Commun. 4:1881. doi: 10.1038/ncomms2898

Voskuil, M. I., Bartek, I. L., Visconti, K., and Schoolnik, G. K. (2011). The response of Mycobacterium tuberculosis to reactive oxygen and nitrogen species. Front. Microbiol. 2:105. doi: 10.3389/fmicb.2011.00105

Wang, Y. F., Hodgkinson, V., Zhu, S., Weisman, G. A., and Petris, M. J. (2011). Advances in the understanding of mammalian copper transporters. Adv. Nutr. 2, 129-137. doi: 10.3945/an.110.000273

Wei, C. J., Lei, B. F., Musser, J. M., and Tu, S. C. (2003). Isoniazid activation defects in recombinant Mycobacterium tuberculosis catalase-peroxidase (KatG) mutants evident in InhA inhibitor production. Antimicrob. Agents Chemother. 47, 670-675. doi: 10.1128/AAC.47.2.670-675.2003

WHO.int [homepage on the Internet]. World Health Organization [uptated 19 November 15; cited 19 November 15]. Available online at: http://www.who.int/ mediacentre/factsheets/fs104/en/.

Wolschendorf, F., Ackart, D., Shrestha, T. B., Hascall-Dove, L., Nolan, S. Lamichhane, G., et al. (2011). Copper resistance is essential for virulence of Mycobacterium tuberculosis. Proc. Natl. Acad. Sci. U.S.A. 108, 1621-1626. doi: 10.1073/pnas.1009261108

Zabinski, R. F., and Blanchard, J. S. (1997). The requirement for manganese and oxygen in the isoniazid-dependent inactivation of Mycobacterium tuberculosis enoyl reductase. J. Am. Chem. Soc. 119, 2331-2332. doi: 10.1021/ja9639731

Conflict of Interest Statement: The authors declare that the research was conducted in the absence of any commercial or financial relationships that could be construed as a potential conflict of interest.

Copyright (C) 2018 McCarron, McCann, Devereux, Kavanagh, Skerry, Karakousis, Aor, Mello, Santos, Campos and Pavan. This is an open-access article distributed under the terms of the Creative Commons Attribution License (CC BY). The use, distribution or reproduction in other forums is permitted, provided the original author(s) and the copyright owner(s) are credited and that the original publication in this journal is cited, in accordance with accepted academic practice. No use, distribution or reproduction is permitted which does not comply with these terms. 